CORRECTION

View Article Online

View Journal I View Issue

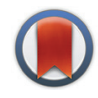

CrossMark

Cite this: Food Funct., 2016, 7, 1711

DOI: $10.1039 /$ c6fo90008a

www.rsc.org/foodfunction

\section{Correction: In vitro analysis of partially hydrolyzed guar gum fermentation differences between six individuals}

\author{
Justin Carlson, ${ }^{a}$ Julian Esparza, ${ }^{a}$ Jonathon Swan, ${ }^{a}$ David Taussig, ${ }^{b}$ Jerry Combs ${ }^{\mathrm{b}}$ and \\ Joanne Slavin*a \\ Correction for 'In vitro analysis of partially hydrolyzed guar gum fermentation differences between six \\ individuals' by Justin Carlson, et al., Food Funct., 2016, DOI: 10.1039/c5fo01232e.
}

In the original article, the name of the third author was misspelled. The corrected spelling of this name is given above. The Royal Society of Chemistry apologises for these errors and any consequent inconvenience to authors and readers. 